\title{
Bioconversion of Egypt's Agricultural Wastes into Biogas and Compost
}

\author{
Mohamed Elfeki ${ }^{1 *}$, Ebtesam Elbestawy $^{2}$, Emil Tkadlec $^{1,3}$ \\ ${ }^{1}$ Department of Ecology and Environmental Sciences, Faculty of Science, Palacký University, \\ Šlechtitelů 27, 78371 Olomouc, Czech Republic \\ ${ }^{2}$ Department of Environmental Studies, Institute of Graduate Studies and Research, Alexandria University, \\ 163 Horria Ave., P.O. Box 832 El-Shatby, Alexandria, Egypt \\ ${ }^{3}$ Institute of Vertebrate Biology, AS CR, Květná 8, 60365 Brno, Czech Republic
}

Received: 7 February 2017

Accepted: 28 March 2017

\begin{abstract}
This study focuses on the bioconversion of agricultural wastes (AWs) in rural Egypt. We analyzed data derived from literature to implement a future image suiting Egypt's situation. Despite the limited information in the field of management of agricultural wastes in Egypt and the gap between formal and practical data, the studies consistently showed that bioconversion is suitable to sustainably treat the unused part of AWs, which is about $52 \%$ of a total of $46.7 \times 10^{6}$ tons year ${ }^{-1}$. Bioconversion can convert those AWs into about $12.6 \times 10^{9} \mathrm{~m}^{3}$ year-1 of biogas with about $60 \%$ methane, which is equal to $7.6 \times 10^{9} \mathrm{~m}^{3}$ of natural gas (NG), and $/$ or $\approx 10 \times 10^{6}$ tons year ${ }^{-1}$ of compost. The produced biogas from anaerobic digestion (AD) can contribute to about $13 \%$ of the Egypt's total NG production; meanwhile, compost will increase the total production of fertilizers in Egypt at more than $60 \%$. This suggests that decision makers, researchers, and engineers should draw more attention to bioconversion as an efficient management tool for resolving the growing problem of agricultural wastes in rural areas.
\end{abstract}

Keywords: agricultural wastes, biogas in Egypt, bioconversion, compost in Egypt, organic wastes

\section{Introduction}

Egypt is an agricultural country because the yields of many agricultural crops in Egypt are among the highest in the world, although the total area of arable land is only 3.3 million hectares [1]. Hence, a substantial amount of agricultural wastes (AWs) is generated and has become a major environmental problem faced by rural areas in Egypt; meanwhile, it may become a source of clean energy

*e-mail: elfekimkm@hotmail.com and organic fertilizers, but the current utilization of those AWs is inefficient. An amount of $18 \%$ is used as fertilizer, another $30 \%$ as animal fodder, and the remainder $(52 \%)$ are unused wastes that are burnt directly in fields or in low-efficiency burners as ways of management and/or disposal causing loss of organic matter and also pollution problems [2], and consequently lead to unfavourable health outcomes and the spread of infectious diseases [3], in addition to greenhouse gas emissions that increase global warming [4]. Because AWs have high organic matter, they are amenable to bioconversion techniques such as composting, which is one of the best-known recycling processes through which organic wastes produce 
organic compost [5], and AD (biogas) technology, which is a promising treatment method applied worldwide to convert biomass into biogas and organic digestate [6]. The produced compost from composting and digestate from biogas techniques can be used as biofertilizers that can replace chemical fertilizers, minimizing environmental pollution and health damage, enhancing crop yield (in conjunction with reducing costs involved in consuming nitrogen fertilizers), and consequently increasing revenue for farmers [7].

The aim of this review is to identify the major problems of AW management in Egypt in order to propose effective bioconversion technologies to solve such problems. In this paper we have analyzed data derived from 74 pieces of literature, including four practical experiences in order to gather indications and evidence of successful performance of both composting and the AD process in treating Egypt's AWs.

\section{Situation Overview}

\section{Agricultural Wastes in Egypt}

The rural population in Egypt is about 53\% of the total population in the country. From a total of 19.9 million working Egyptian citizens, there are 11 million living in rural areas. About $51 \%$ of the 11 million participate in agriculture and the rest in trade, services, and rural industries. The population of the people exposed to poverty in Egypt is about 10.7 million inhabitants, from which $70 \%$ live in rural areas - especially in Upper Egypt [8]. In the country, the average temperatures over the northern coast vary from a minimum of $9.5^{\circ} \mathrm{C}$ to a maximum of $17^{\circ} \mathrm{C}$ during winter, and in summer from a minimum of $23^{\circ} \mathrm{C}$ to a maximum of $32^{\circ} \mathrm{C}$. In the central and the southern parts, daytime temperatures are hotter, especially in summers where the average high temperatures can exceed $40^{\circ} \mathrm{C}$ [9]. Data over agricultural residues in Egypt are scattered throughout the literature [10]. Data on AWs in Egypt reveal that there is an approximate amount of 33.4 million tons of waste generated annually (Table $1)$; in addition, there is an annual amount of animal waste consisting of about $11 \times 10^{6}$ tons of cattle manure and $2.3 \times 10^{6}$ tons obtained from poultry farms [5].

Furthermore, agro-industrial wastes such as bagasse of magnitude $4.7 \times 10^{6}$ tons result from sugar cane. This bagasse is mostly used for heat/electricity generation in the sugar mills, but with poor efficiency and black smoke emissions. In addition, there are about $1.6 \times 10^{6}$ tons of rice husk used as a source of energy for the milling process and sold as animal fodder [3].

\section{The Current Bioconversion of Agricultural Wastes in Egypt}

A two-year survey of 143 villages representing the rural areas in Egypt revealed that there were no composting facilities in those villages, but the farmers participate in
Table 1. Amounts of annual agricultural wastes in Egypt [5]

\begin{tabular}{|c|c|}
\hline Crop residue & Million tons \\
\hline Wheat straw & 6.9 \\
\hline Sugar cane residues & 6.8 \\
\hline Maize residues & 4.5 \\
\hline Rice straw & 3.6 \\
\hline Banana residues & 1.7 \\
\hline Trees-trimming residues & 1.7 \\
\hline Cotton stalks & 1.6 \\
\hline Tomato & 1.11 \\
\hline Public garden residues & 1.14 \\
\hline Sorghum residues & 1.2 \\
\hline Vegetable residues & 0.71 \\
\hline Date palm residues & 0.66 \\
\hline Sesame straw & 0.56 \\
\hline Beans straw & 0.35 \\
\hline Sugar beet residues & 0.32 \\
\hline Potato & 0.317 \\
\hline Barley straw & 0.2 \\
\hline Pea straw & 0.042 \\
\hline Lentil straw & 0.012 \\
\hline Total & 33.4 \\
\hline
\end{tabular}

composting on an individual basis and use of food waste as animal fodder, but the most common practice is direct dumping (Fig. 1) on the banks of drains and canals [11].

There are about 68 composting facilities in Egypt, but they are meant for processing domestic organic wastes, with a processing design capacity of 10 tons hour ${ }^{-1}$ each, but the total actual processed organic wastes represented by those facilities are $<37 \%$ of the designed capacities [12]. On the other hand, anaerobic digesters in Egypt were

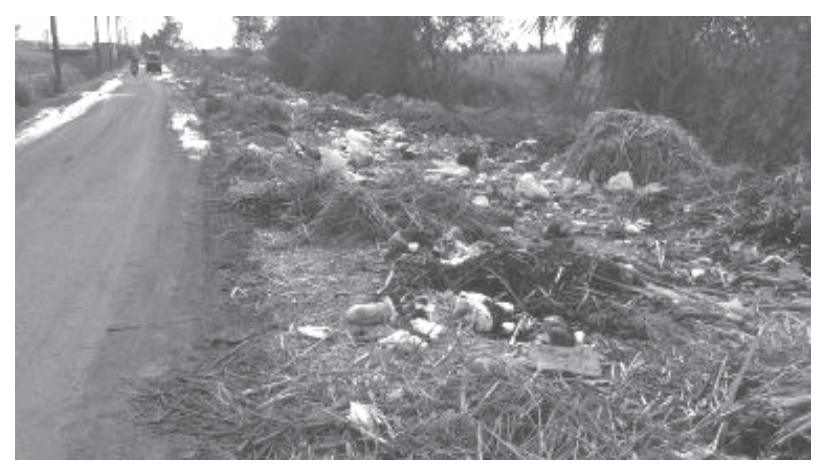

Fig. 1. Open dumping of unused agricultural wastes on the banks of drains and canals in Egypt. Source: www.isiimm.agropolis. org/swamma/image/waste_problem_1.jpg 
mainly small-scale plants with a volume of $5-50 \mathrm{~m}^{3}$ and they are either the Indian type for animal droppings or the Chinese type for crop residues and vegetable wastes, but recently these digesters have been modified into two-stage fermentation systems, fed with both animal droppings and crop residues; there are a few examples of large-scale digesters such as in Elgabal Elasfar [13]. The amount of digestate from anaerobic digesters is a little more than $40 \%$ of the original substrates by weight [14]. It has been concluded by El- Mashad [15] that the two major flows of unused AWs in Egypt are rice straw and cattle/buffalo manure. These two waste streams can better be treated via a two-step biological process: firstly $\mathrm{AD}$ of manure mixed with rice straw and secondly composting the resulting effluent together with rice straw. In general, biological digestion of lignocellulosic materials in biomass needs pretreatment [16]; because lignin covers cellulose and hemicellulose for the removal of both lignin and hemicelluloses, decreasing the crystallinity of cellulose makes it easy for enzymes to reach cellulose in order to increase hydrolysis efficiency [17]. The available pretreatment techniques are physical, chemical, or biological. Also, a combination of two or more pretreatment techniques has shown promising results; however, chemical and thermo-chemical techniques are currently the most effective and promising pretreatment methods for lignocellulosic materials [18].

\section{Energy and Fertilizers in Egypt}

Energy consumption in Egypt in 2015 was dependent mainly on gas (53\%), oil (41\%), hydroelectric plants (3\%), coal $(2 \%)$ and renewable energy $(1 \%)$. About $70 \%$ of Egypt's electricity is fueled by NG and the remainder by petroleum and renewable energy (mostly hydroelectricity). The country's electrical energy-generating capacity as of May 2015 was 31.45 gigawatts (GW) - slightly higher than the expected peak demand of $30 \mathrm{GW}$ - and there is a need of oil and diesel fuel to cover the shortfall in summer months [19]. The total NG production of Egypt in 2015 was $57.6 \times 10^{9} \mathrm{~m}^{3}$, whereas consumption in the same year was $52.72 \times 10^{9} \mathrm{~m}^{3}$ [20]. Egyptian production of fertilizers is 15.5 million tons, while consumption is 8.5 million tons, which indicates a surplus of 7 million tons. However, there is a crisis, because companies indulge in exporting in addition to the imbalance in the distribution mechanism [21].

\section{Bioconversion through Anaerobic and Aerobic digestion}

\section{AD Process}

This is a collection of processes through which microorganisms break down biodegradable materials in the absence of oxygen, and the majority of the chemical energy contained within the starting material is converted by methanogens into biogas to be used as a renewable energy, alongside a residue (digestate) rich in nutrients
[22]. The populations of anaerobic microorganisms take a period of time to establish themselves to be fully effective in order to initiate a series of metabolic reactions such as: Hydrolysis: Large polymers are broken down by enzymes. Acidogensis: Fermentations of organic matter producing acetate $\left(\mathrm{C}_{2} \mathrm{H}_{3} \mathrm{O}_{2}\right)$, volatile fatty acids (VFAs), carbon dioxide $\left(\mathrm{CO}_{2}\right)$, and hydrogen $\left(\mathrm{H}_{2}\right)$.

Acetogenesis: Breakdown of VFAs to $\mathrm{C}_{2} \mathrm{H}_{3} \mathrm{O}_{2}$ and $\mathrm{H}_{2}$. Methanogenesis: Converting $\mathrm{C}_{2} \mathrm{H}_{3} \mathrm{O}_{2}$ and $\mathrm{H}_{2}$ to methane $\left(\mathrm{CH}_{4}\right)$ and $\mathrm{CO}_{2}(23)$.

The optimal conditions of $\mathrm{AD}$ are $\mathrm{pH}$ 5.2-6.3 and $\mathrm{C} / \mathrm{N} 10 / 1-45 / 1$ in hydrolysis/acidogenesis, whereas in methanogenesis they are $\mathrm{pH}$ 6.7-7.5 and $\mathrm{C} / \mathrm{N}$ $20 / 1-30 / 1$. Temperature has to be $25-35^{\circ} \mathrm{C}$ in hydrolysis/acidogenesis phases, but in methanogenesis it has to be $32-42^{\circ} \mathrm{C}$ (mesophilic) and $50-58^{\circ} \mathrm{C}$ (thermophilic) [24]. Furthermore, free ammonia $\left(\mathrm{NH}_{3}\right)$ resulting from anaerobic degradation of the nitrogen-rich protein components decreases the activity of methanogens [2526]. In order to avoid failure in the process of anaerobic digestion and to increase the yield of biogas, different AW streams must be mixed and treated together (co-fermented or co-digested) with industrial sludge or cattle slurry [27]. The potential benefits of co-digestion are the dilution of toxic compounds such as volatile fatty acids (VFAs) and $\mathrm{NH}_{3}$; improving the balance of nutrients, improving the $\mathrm{C}: \mathrm{N}$ ratio, and stabilizing digester performance by stabilizing the $\mathrm{pH}$ value [28-30] and increasing biogas yield [31]. The organic loading rate (OLR) is substrates fed per day per unit of digester volume and also defined as the amount of volatile solids (VS) or the chemical oxygen demand of substrates fed per day per unit of digester volume. A total solid concentration of $15.2 \%$ has been reported to lead to the highest yield of gas, but in case of fresh cattle dung employed as a mono substrate, it has to be mixed with water on a unit volume basis $(1 / 1$, water / dung) before feeding into the digester [21]. Mumme et al. [32] have documented that hydrolysis of complex organic matter into soluble compounds is the rate-limiting step of anaerobic processes for wastes with a high solid content, and according to Charles et al. [33] various physical, chemical, and enzymatic pre-treatments are required to avoid the challenges/difficulties due to the hydrolysis of lignocellulosic materials and increase substrate solubility; on the other hand, $\mathrm{AD}$ has some disadvantages such as long retention times and low removal efficiency of organic compounds [34]; furthermore, it can cause some traffic problems, health and safety risks because of the pathogenic contents of feedstock/digestate, some explosion risks, and visual impact due to the large tanks. So the AD plants have to be placed and designed in a way that eliminate all previous risks and the digestate has be treated to become pathogen-free and stable with low odor [35].

There are two types of fermentation, wet (10-25\% dry matter), which is the most commonly used technique, and dry (30-40\% dry matter) [36], which is an emerging process [34]. AD can be either single-stage (all reactions take place in one chamber) or multiple stage (reactions take place separately) [37]. Multiple stage ADs have high 
efficiency [38] because of the enrichment of bacteria in each phase, degrading complex organics, stability, and no overloading [39]. The feedstock might be continuous (in both single and multiple stages) [37] or batch, which is simple, inexpensive, and assesses the rate of digestion easily [40], but the disadvantages of batch process are high fluctuations in gas yield, gas quality, and biogas loss during emptying the bioreactors, and it restricts the bioreactor heights [41].

Biogas produced from $\mathrm{AD}$ is a blend consisting by volume mainly of methane $\left(\mathrm{CH}_{4} \approx 60 \%\right)$, carbon dioxide $\left(\mathrm{CO}_{2} \approx 40 \%\right)$, and small traces of hydrogen sulphide $\left(\mathrm{H}_{2} \mathrm{~S}\right)$, hydrogen $\left(\mathrm{H}_{2}\right)$, nitrogen $\left(\mathrm{N}_{2}\right)$, carbon monoxide $(\mathrm{CO})$, oxygen $\left(\mathrm{O}_{2}\right)$, water vapor $\left(\mathrm{H}_{2} \mathrm{O}\right)$, or other gases and vapors of various organic compounds [42]. It has a density of $1.3 \mathrm{~kg} \mathrm{~m}^{-3}$, ignition temperature $650-750^{\circ} \mathrm{C}$, explosion limits $6-12 \%$ gas to air, and it is flammable if it contains $>45 \% \mathrm{CH}_{4}$ [43]. Practical and costeffective technologies are currently available to remove contaminants from biogas, including siloxanes that result from domestic wastes [44]. The calorific value of methane is $21-24 \mathrm{MJ} / \mathrm{m}^{3}$, or about $6 \mathrm{kWh} / \mathrm{m}^{3}$ of heat or $2 \mathrm{~kW} / \mathrm{m}^{3}$ electricity and the rest is heat, which is often used for cooking, heating, lighting, or electricity generation [45]. The energy content of $1.0 \mathrm{~m}^{3}$ of purified biogas is equal to $1.1 \mathrm{~L}$ of gasoline, $1.7 \mathrm{~L}$ of bio-ethanol, or $0.97 \mathrm{~m}^{3}$ of NG [46]. Digestate is the end product of digested material from a biogas plant rich in nitrogen $(\mathrm{N})$, phosphorus $(\mathrm{P})$, and potassium $(\mathrm{K})$ in available form that can replace inorganic fertilizers after curing it aerobically, and afterwards screening it for any undesirable materials for quality improvement [47]. The quality of digestate depends on the nature of the waste substrate, for instance it can contain persistence organic contaminants if AWs contain pesticide residues or antibiotics, but it is rich in nutrients and it also helps in enhancing the humus balance in the soil, and dewatering the digestate produces bulky fibre with low nutrient concentration (low-grade fertilizer) and liquor with high nutrients (high-grade fertilizer). The bulky fiber can be used as a soil conditioner or further processed to produce high-quality compost [42].

\section{Aerobic Digestion (Composting)}

It is the biological decomposition of organic materials by microorganisms under controlled aerobic conditions to a relatively stable humus-like material called compost, and the process is usually run as a batch process [4849]. It is suitable for AWs such as livestock manures, bedding, and various residual plant materials (straw, culls, or on-farm processing wastes). It has to take place in a well-managed process to obtain a valuable product with minimum negative environmental impacts. The composting process reduces AW volume, moisture content, viable weed seeds, insect larvae (flies problems), and odor; it also reduces/eliminates pathogens due to the high process temperature (thermophilic) and it produces a humus-like compost (40-50\% of the starting substrate) with fine, moderate, or coarse texture and rich in nutrients to be used as a biofertilizer [48, 50], which subsequently can be used in organic agriculture to produce a top-quality food by enhancing the environment and maintaining soil fertility [51], which leads to increasing crops yield [49]. The duration of the composting process reaches 90 days, but it can also last for 75 days [52]. Moreover, it can take place within only 35 days in the case of composting AWs using microencapsulated bacteria and enzymes [53]. There are some factors that affect the composting process such as carbon-to-nitrogen ratio (C:N) 25:1$30: 1$, moisture content $50-60 \%$, aeration (oxygen $>5 \%$ ), temperature $54-60^{\circ} \mathrm{C}$, porosity $30-36$, and $\mathrm{pH}$ 6.5-7.5 [5455]. The most commonly used methods for composting are windrows, aerated static piles, and aerated bins (invessel composting).

Windrows are the most common method of composting, which involves stacking organic wastes into windrows that are turned periodically. It is a simple technique that requires few control measures other than monitoring temperature and moisture. Windrow height ranges 3-5 feet and the base width is about 10-15 feet and it can be mechanically aerated by turning the windrow. The minimum composting time is one month in the turned windrow followed by at least two months in a curing pile.

Aerated static piles in which the organic wastes are placed in piles that are aerated either by turning or by means of forced air through perforated pipes. Aeration rate may be gradually reduced to zero after four weeks.

Aerated bins (in-vessel composting) are either stirred (continuous flow) or unstirred (patch). Continuous-flow systems are more highly mechanized than batch systems and they produces well-stabilized end products within one month that should be cured in a stockpile for several weeks before use. Aeration in batch mode can also be provided throughout perforated pipe, with the air under positive or negative pressure [56].

\section{Results and Discussion}

\section{Analysing the Data Presented above Revealed the Following:}

Agricultural activities in Egypt generate annually to about $46.7 \times 10^{6}$ tons of AWs (Table 2), from which $52 \%$ are unused and improperly disposed of.

Composting facilities in Egypt deal mostly with organic domestic wastes and there are almost no composting plants in rural areas except for the participation of farmers on an individual basis in composting of organic matter. The most common practice is the direct dumping of AWs on the banks of drains and canals. Furthermore, AD is applied in small-scale plants with a volume of $5-50 \mathrm{~m}^{3}$, and they are insufficient.

There is a need for oil and diesel fuel to cover the shortfall of electrical energy in summer months. Meanwhile, NG production is almost enough for generating 70\% of Egypt's electricity. Hence the Egyptian government has to take the growth of energy consumption 
Table 2. Specifications of agricultural wastes in Egypt.

\begin{tabular}{|c|c|c|}
\hline Specifications & Million tons & Percentage \\
\hline Crop waste & 33.4 & $71.5 \%$ \\
\hline Cattle manure & 11.0 & $23.5 \%$ \\
\hline Poultry farm waste & 02.3 & $5 \%$ \\
\hline Total AW & $\mathbf{4 6 . 7}$ & $\mathbf{1 0 0 \%}$ \\
\hline Managed AWs & 22.4 & $48 \%$ \\
\hline Unused AWs & 24.3 & $52 \%$ \\
\hline
\end{tabular}

in the near and far future into consideration. There is a crisis in the field of fertilizers in Egypt that could lead to negative impacts on agricultural activities.

Bioconversion via aerobic digestion converts AWs into compost; meanwhile anaerobic digestion can sustainably convert those wastes into biogas and digestate, with a minimum or no need for inducing heat energy for the process.

\section{Suggested Scenarios}

Based on these results, we proposed two scenarios to cope with the problem of the unused AWs in Egypt as follows:

\section{First Scenario}

Apply AD using a mixed substrate of food waste, fresh crop wastes, and cattle manure in the prevailing temperature, and construct either small-scale or semicentralized $\mathrm{AD}$ plants. When we apply the average yield of all discussed experimental studies and practical applications $\left(520 \mathrm{~m}^{3}\right.$ ton $\left.^{1}\right)$, the total projected annual biogas yield from the unused AWs will be: $\left(24.3 \times 10^{6}\right)$ $\times 520 \approx 12.6 \times 10^{9} \mathrm{~m}^{3}$ (Fig. 2). In addition, the produced digestate will be $40 \%$ of total waste substrate as it is in the literature. So the projected annual digestate yield will be: $\left(24.3 \times 10^{6}\right) \times 0.40 \approx 9.7 \times 10^{6}$ tons (Fig. 3). Afterward the produced digestate must be matured by a short aerobic digestion for quality to be guaranteed.

\section{Second Scenario}

It is the application of on-site composting plants directly after harvesting to use a fresh mixture of AW streams. Here we can also use either small-scale or semicentralized plants. The projected annual compost yield of the unused AWs (Fig. 4) from aerobic digestion when we apply the minimum average yield of $42 \%$ based on the experimental studies and practical applications will be: $\left(24.3 \times 10^{6}\right) \times 0.42 \approx 10.21 \times 10^{6}$ tons.

The major result of applying the first scenario of $\mathrm{AD}$ bioconversion is converting an amount of $24.3 \times 10^{6}$ tons of Egypt's AWs into $\approx 12.757 \times 10^{9} \mathrm{~m}^{3}$ of biogas and $\approx 9.7 \times 10^{6}$ tons of digestate, whereas by applying the second scenario of aerobic digestion, the same amount of

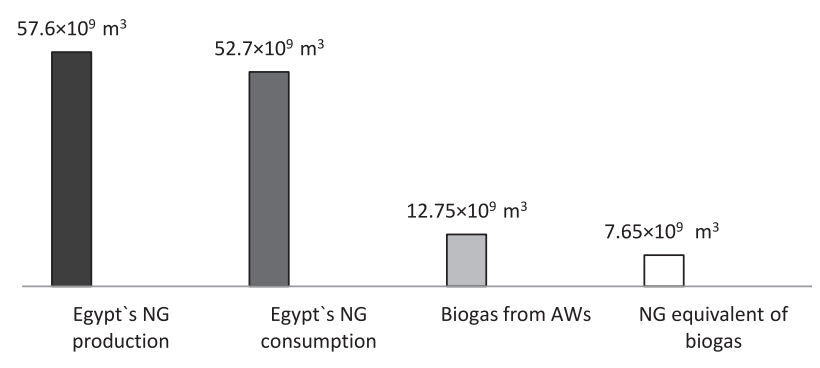

Fig. 2. Projected annual gas yield from anaerobic co-digestion of unused agricultural wastes in Egypt.

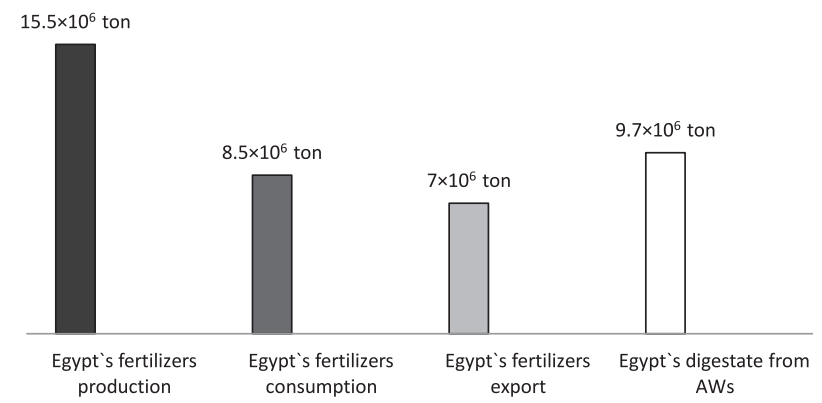

Fig. 3. Projected annual digestate yield from anaerobic codigestion of unused agricultural wastes in Egypt.

AWs will be converted into $10.21 \times 10^{6}$ tons of compost. These two approaches can solve not only the problem of AW management but also contribute to minimizing the negative impacts on both environment and public health. Biogas from AD can add a substantial amount to Egypt's gas production for domestic use, covering the shortfall of electrical power and replacing oil and diesel fuel. Digestate from $\mathrm{AD}$ or compost from composting can add $\approx 60 \%$ of Egypt's total fertilizer production, increasing organic agriculture and crop yield by enhancing soil properties.

In the first scenario we propose anaerobic co-digestion, because the main concept of applying $\mathrm{AD}$ to convert AWS into a widely usable biogas as a clean and renewable fuel [57], and a digestate to replace chemical fertilizers, thereby enhancing quality yield of agricultural crops and protecting the environment [58-

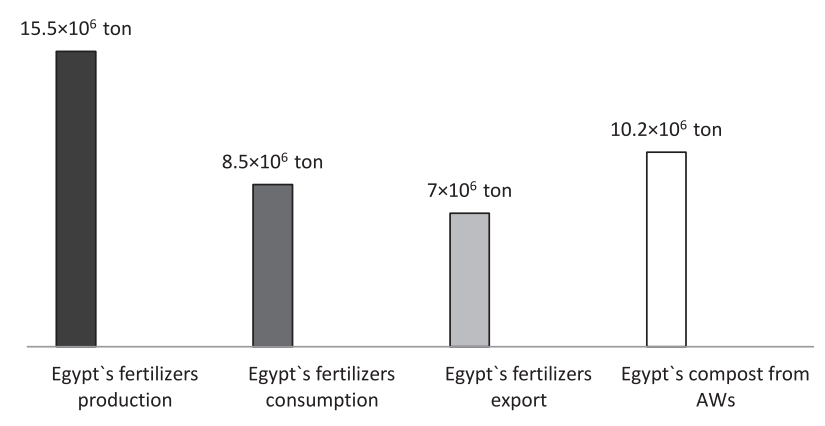

Fig. 4. Projected annual compost yield from aerobic digestion (composting) of unused agricultural wastes in Egypt. 
59]. There is evidence that the biogas yield from vegetable leaves is $0.23-0.33 \mathrm{~m}^{3} \mathrm{~kg}^{-1}$ vs, straw (rice, maize,...) $0.092-0.33 \mathrm{~m}^{3} \mathrm{~kg}^{-1}$ vs, pig manure $0.36 \mathrm{~m}^{3} \mathrm{~kg}^{-1}$ vS, cow manure $0.28 \mathrm{~m}^{3} \mathrm{~kg}^{-1}$ vS, and rotten fruits $0.21-0.51 \mathrm{~m}^{3} \mathrm{~kg}^{-1}$ vs $[24,60]$. Experimentally, co-digestion of a mixture of cow manure and fruit and vegetable waste (50:50 by weight) produced $450 \mathrm{~m}^{3}$ ton $^{-1}$ vs at $35 \pm 0.5^{\circ} \mathrm{C}$ [61], whereas a mixture of buffalo manure and maize silage (70:30 by VS content) at $35 \pm 1^{\circ} \mathrm{C}$ produced $358.23 \pm 44.15 \mathrm{~m}^{3}[62]$. It has also been shown that meadow grass with its biochemical methane potential value of $388 \pm 30 \mathrm{~mL} \mathrm{~g}^{-1}$ vs has a yield increase of $114 \%$ when codigested with manure in a continuous stirred tank reactor [63], and when a mixture of solid cattle slaughterhouse waste, manure, various crops, and municipal solid wastes are batch-digested in thermophilic process, a methane yield of $655 \mathrm{~mL} \mathrm{~g}^{-1}$ vs was obtained [64]. The approximate biogas yield estimated in Denmark by co-digestion for harvest residues including straw, stems, sugar beet toppings, and fibrous mater is $375 \mathrm{~m}^{3}$ ton $^{-1}$, and animal manure (dough) was $200-500 \mathrm{~m}^{3}$ ton $^{-1}$; food industry waste, confectionary waste, and whey was $400-600 \mathrm{~m}^{3}$ ton slaughterhouse waste flotation sludge, animal fat, stomach and gut contents and blood was $550-1,000 \mathrm{~m}^{3}$ ton $^{-1}$; waste from paper industry was 400-800; sludge from gelatin and starch production was 700-900 $\mathrm{m}^{3}$ ton $^{-1}$; source-separated bio-wastes were $400-500 \mathrm{~m}^{3}$ ton $^{-1}$; and market waste was 500-600 $\mathrm{m}^{3}$ ton $^{-1}$ [65]. Budzianowski [66] has reported that the concentration of $\mathrm{CH}_{4}$ in biogas can reach $98-99 \%$ by the injection of coke oven gas to an $\mathrm{AD}$ reactor (COGAD). Furthermore, Heo et al. [67] have experimentally demonstrated in Korea that the degradability of vegetables varied from $65-70 \%$ with a methane yield of $0.49 \mathrm{~L} \mathrm{~g} \mathrm{~g}^{-1} \mathrm{vs}$ at $35^{\circ} \mathrm{C}$ after 40 days HRT, whereas Zhang et al. [68] have equally noted that food waste contained appropriate nutrients for anaerobic microorganisms and through batch digestion under thermophilic conditions $\left(50^{\circ} \mathrm{C}\right)$ after 28 days, biogas was produced at a magnitude $0.44 \mathrm{~L} \mathrm{~g} \mathrm{~g}^{-1} \mathrm{vs}$.

However, we have selected two practical applications as examples to demonstrate the benefits of $\mathrm{AD}$ as follows:

Case Study I: Chen et al. [69] have shown that a centralized anaerobic digester system in the area of Sacramento, California, for the production of biogas energy has a yield between $530-750 \mathrm{~m}^{3}$ ton $^{-1}$ of waste consisting of five types of food wastes from a soup processing plant, a cafeteria, a commercial kitchen, a fish farm, and grease trap collection service. These five waste streams were successfully digested both individually and as a mixture. Fish and grease trap wastes showed microbial inhibition during the initial period of batch digestion under thermophilic conditions, causing a one-to-two week lag phase in biogas production; meanwhile, continuous digestion of the mixed food wastes under mesophilic conditions was successful and was performed with other nutrient-rich materials such as animal manure and meatbased products. The resulting digestate contained many nutrients and could thus be used as a plant fertilizer.

Case study II: Alaa El-Din et al. [70] have previously demonstrated a practical experiment that was made shortly before 1986 by the Egyptian armed forces to evaluate a two-stage biogas digester designed to match the needs of one of the army camps and to extract the technical knowledge needed for the future. The total capacity of this biogas plant was $190 \mathrm{~m}^{3}\left(150 \mathrm{~m}^{3}\right.$ digesting volume). The plant included a fixed-film compartment $\left(20 \mathrm{~m}^{3}\right)$ and it was operated for 422 days. During this period, 203 tons of the camp fresh refuse were fed to the digester at an average rate of $480.9 \mathrm{~kg} \mathrm{day}^{-1}$, containing $248.5 \mathrm{~kg}^{-1 a y}{ }^{-1}$ total solids and consisting of $85.5 \%$ dry bread pieces, $9.8 \%$ kitchen refuse, and $4.7 \%$ spoiled cooked food. The average biogas produced was $200.6 \mathrm{~m}^{3}$ day $^{-1}$. However, preliminary economic evaluation indicated a payback period of less than six months for the investment costs (20,000 Egyptian pounds) based on international fuel prices. Results of this practical experiment were positive and encouraging for the Egyptian Ministry of Defence.

All previous laboratory experiments have proved that anaerobic co-digestion of organic wastes produces a biogas yield ranging from the lowest $\left(200 \mathrm{~m}^{3}\right.$ ton $^{-1}$ vs $)$ to a high of $1,000 \mathrm{~m}^{3}$ ton $^{-1}$ vs with an average biogas yield of $\approx 520 \times 10^{9} \mathrm{~m}^{3}$ ton $^{-1}$ of wastes.

Case study I supports the co-digestion method, which is suitable for AWs because it has the required mixture of food wastes and cattle manure that could produce biogas yield of $530-750 \mathrm{~m}^{3}$ with an average of $640 \mathrm{~m}^{3}$ ton $^{-1} \mathrm{vs}$.

Case study II has been performed using Egypt's materials and experience in the prevailing temperature, and the digester has a biogas yield of $417 \mathrm{~m}^{3}$ ton $^{-1}$ of organic wastes. It also showed great success with a payback period of less than six months for the starting investments.

The literature reported that the resulting digestate is about $40 \%$ from the total input and is suitable to be used in agriculture.

In the second scenario, we suggest that AWs are suitable to be composted by aerobic digestion in order to be converted into organic fertilizers and soil amendments. This process takes place within a minimum composting time of one month in the turned windrow procedure followed by at least two months in a curing pile. Afterward the compost is ready to be spread or bagged and marketed [56]. Experimental results showed that a mixture consisting of $60 \%$ cattle manure and $40 \%$ green waste allowed for the highest process temperature and organic material decomposition [55] producing compost of up to $55 \%$ from the initial substrate [71]. A study was conducted to assess compost production on a large commercial scale using three different AWs such as date trees, olive trees, and maize mixed with sheep manure. Results of this study indicated the importance of mesophilic aerobic cellulose decomposing bacteria, and compost was produced in 53$55 \%$ from the initial input after 90 days [72].

We have selected two practical applications from Egypt in the prevailing temperature and work conditions to demonstrate the benefits of aerobic digestion as follows:

Case study III: A successful project was implemented 
Table 3. Feasibility of Mansoura composting plants in Egyptian pounds [73].

\begin{tabular}{|c|c|c|c|}
\hline Specifications & $\begin{array}{c}\text { First } \\
\text { year }\end{array}$ & $\begin{array}{c}\text { Second } \\
\text { year }\end{array}$ & $\begin{array}{c}\text { Third } \\
\text { year }\end{array}$ \\
\hline Total revenue & 252,175 & 653,675 & 803,275 \\
\hline Total costs & 301,137 & 453,998 & 513,040 \\
\hline $\begin{array}{c}\text { Income without capital } \\
\text { depreciation }\end{array}$ & $-(48,962)$ & 199,677 & 290,235 \\
\hline
\end{tabular}

by the Egyptian Environmental Affairs Agency in Mansoura, Egypt. The composting plants operated for 300 days per year ${ }^{-1}, 7$-hour shifts per day ${ }^{-1}$ with 50 employees, and the processing (Table 3 ) was feasibly about 75 tons day $^{-1}$ of domestic organic refuse $\left(22,500\right.$ tons year $\left.{ }^{-1}\right)$. It produced about 52.5 tons day ${ }^{-1}$ of compost (15,750 tons year ${ }^{-1}$ ), which was $70 \%$ of the total processed organic waste by weight [73].

Case study IV: The Dutch Louis Bolk Institute [74] reported in 2010 about a composting facility in Alexandria that processed AWs in 2008/2009. These AWs consisted of rice straw 1.324 , wood shavings 0.785 , poultry manure 2.389 , cow manure 20.028 , clay 11.916 , and green waste (water hyacinth from irrigation channels) 5.211 tons. The composting process in windrows and took six weeks. The total input was 41.653 tons and the total compost yield was 17.560 tons, which was $42 \%$ of the total input.

Case study III supports composting feasibility of organic wastes by showing a profit starting from the second year. This is an evidence of success, whereas case study IV showed that the compost yield of AWs was about $42 \%$ from total input.

The data above reveal that the final production of compost by applying aerobic digestion ranged between $42 \%$ and $55 \%$. We took in scenario 2 , the lowest yield (42\%), to be applied in the second suggested scenario.

\section{Conclusions}

Based on the previous discussion we concluded that bioconversion of Egypt's AWs with mixed substrates can be an effective treatment option to contribute to minimizing environmental and health problems that usually result from the improper treatment of those wastes. Herein, we suggest two scenarios for treating AWs in Egypt. The first scenario is applying $\mathrm{AD}$ followed by maturation for the digestate to treat an amount of $24.3 \times 10^{6}$ ton year ${ }^{-1}$ of AWs, producing $12.6 \times 10^{9} \mathrm{~m}^{3}$ year ${ }^{-1}$ biogas and $9.7 \times 10^{6}$ ton year ${ }^{-1}$ digestate. The biogas yield equals $7.610^{9} \mathrm{~m}^{3}$ of NG. The second scenario is applying aerobic digestion onsite to produce about $10.21 \times 10^{6}$ tons year ${ }^{-1}$ compost from the same amount of AWs. Both AD and aerobic digestion techniques can be applied using small-scale and/or semicentralized plants. The generated biogas can be used in domestic and industrial activities, and the natural compost can be used to improve the quality of soil and positively developing agriculture in the rural areas in Egypt, and it can also be used in landscaping. These rough calculations are indicative for decision makers but they need more investigation.

\section{Acknowledgements}

We are grateful to the anonymous referees and the editorial board for reviewing this paper.

\section{References}

1. El-MASHAD H.M., LOON W.K., ZEEMAN G. Reuse potential of agricultural wastes in semi-arid regions: Egypt as a case study. Reviews in Environmental Science and Bio/ Technology. 2 (1), 53, 2003.

2. HAMDY Y.A. The current situation of Egyptian agricultural wastes. In: The Proceedings of Anaerobic Treatment of Solid Wastes Workshop, 1998, Mansoura University, Egypt, [in Arabic].

3. NAKHLA D.A., HASSAN M.G., EL-HAGGAR S. Impact of biomass in Egypt on climate change. Natural Science. 5 (6), 678, 2013.

4. RZEŹNIK W., MIELCAREK P. Review Greenhouse Gases and Ammonia Emission Factors from Livestock Buildings for Pigs and Dairy Cows. Pol. J. Environ. Stud. 25 (5), 1813, 2016.

5. ABOU HUSSEIN S.D., SAWAN O.M. The utilization of agricultural waste as one of the environmental issues in Egypt (A case Study). Journal of Applied Sciences Research. 6 (8), 1116, 2010.

6. FERNANDÉZ J., PERÉZ M., ROMERO L.I. Kinetics of mesophilic anaerobic digestion of the organic fraction of municipal solid waste: influence of initial total solid concentration. Bioresour Technol. 101 (16), 6322, 2010.

7. ZAREMANESH H., NASIRI B., AMIRI A. The effect of vermicompost biological fertilizer on corn yield. J. Mater. Environ. Sci. 8 (1), 154, 2017.

8. KRUSEMAN G., VULLINGS W. Rural Development Policy in Egypt towards 2025. Alterra-rapport, 2007, ISSN 1566-7197.

9. World Meteorological Organization. Weather Information for Cairo, 2014. http://worldweather.wmo.int/en/city. html? cityId $=248$

10. SAID N., EL-SHATOURY S., DIAZ D L F., ZAMORANO M. Quantitative appraisal of biomass resources and their energy potential in Egypt. Renewable and Sustainable Energy Reviews. 24, 84, 2013.

11. EL-MESSERY M.A., ISMAIL G.A., ARAFA A.K. Evaluation of municipal solid waste management in Egyptian rural areas. Egypt Public Health Assoc. 84 (1-2), $51,2009$.

12. ZAKI T., KAFAFI A., MINA M.B., ABD EL-HALIM A.M., SABER M. Solid Waste Management in Egypt, annual report of New center for Integrated studies of Land \& Environment (NILE), Published by: Ministry of State for Environmental Affairs, 2013.

13. EL-HAGGAR S.M, MOUNIR G, GENNARO L. Agricultural waste as an energy source in developing countries, a case study in Egypt on the utilization of agricultural waste through complexes. International Centre for Science and High Technology (ICS), United Nations 
Industrial Development organization (UNODO), 1, 2004.

14. DE BERE L. Anaerobic digestion of solid waste: state-of-theart. Water Science and Technology. 41 (3), 283, 2000.

15. EL-MASHAD H.M. Solar Thermophilic Anaerobic Reactor (STAR) for Renewable Energy Production. Thesis Wageningen University, the Netherlands- with summary in Dutch, 2003, ISBN: 90-5808-953-3.

16. BOONTIAN N. Conditions of the Anaerobic Digestion of Biomass, International Journal of Biological, Biomolecular, Agricultural, Food and Biotechnological Engineering. 8 (9), 1036, 2014.

17. KUMAR R., WYMAN C.E. Does change in accessibility with conversion depend on both the substrate and pretreatment technology? Bioresour Technol. 100 (18), 4193, 2009.

18. MAURYA D.P., SINGLA A., NEGI S. An overview of key pretreatment processes for biological conversion of lignocellulosic biomass to bioethanol. Biotech. Biotech. 5 (5), 597, 2015

19. EIA, US Energy Information Administration: Egypt International energy data and analysis, 2015. https://www. eia.gov/beta/international/analysis.cfm?iso=EGY

20. THE WORLD FACTBOOK, CIA: Energy Egypt, 2015. https://www.cia.gov/library/publications/the-worldfactbook/geos/eg.html

21. Report no. "42". The fertilizer crisis in Egypt (the problem and the solution), Land Center for Human Rights LCHR, 2007. http://www.lchr-eg.org/archive/105/105-43.htm

22. MERLIN G., BOILEAU H. Anaerobic Digestion of Agricultural Waste: State of the Art and Future Trends. In: TORALES A. (edt) Anaerobic Digestion: Types, Processes and Environmental Impact, Series: Environmental Science, Engineering and Technology Waste and Wastewater Management, Publisher: Nova Science Publishers, Inc NY USA, 2013.

23. THEMELIS N.J., ULLOA P.A. Methane generation in landfills. Renew Energy. 32, 1243, 2007.

24. CHANDRA R., TAKEUCHI H., HASEGAWA T. Methane production from lignocellulosic agricultural crop wastes: A review in context to second generation of biofuel production. Renewable and Sustainable Energy Reviews. 16, 1462, 2012.

25. KHAIRUDDIN N., ABD MANAF L., ALI HASSAN M., HALIMOON N. A.B., KARIM GHANI W.A.W. High Solid Anaerobic Co-Digestion of Household Organic Waste with Cow Manure for Mass and Energy Recovery. Pol. J. Environ. Stud. 25 (4), 1549, 2016.

26. FOUNTOULAKIS M.S., DRAKOPOULOU S., TERZAKIS S., GEORGAKI E., MANIOS T. Potential for methane production from typical Mediterranean agro-industrial byproducts. Biomass Bioenergy. 32, 155, 2008.

27. NOORI M., SAADY C., MASSÉ D.I. Impact of Organic Loading Rate on Psychrophilic Anaerobic Digestion of Solid Dairy Manure. Energies. 8, 1990, 2015.

28. KHALID A., ARSHAD M., ANJUM M., MAHMOOD T., DAWSON L. The Anaerobic Digestion of Solid Organic Waste. Waste Management. 31, 1737, 2011.

29. HARTMANN H., AHRING B.K. Anaerobic digestion of the organic fraction of municipal solid waste: Influence of codigestion with manure. Water Research. 39 (8), 1543, 2005.

30. PATIL V.S., DESHMUKH H.V. Co-Digestion of Vegetable waste with Organic wastes for Energy Generation. A review; Int. Res. J. Biological Sci. 4 (6), 83, 2015.

31. ALQARALLEH R.M., KENNEDY K., DELATOLLA R., SARTAJ M. Thermophilic and hyper-thermophilic codigestion of waste activated sludge and fat, oil and grease. Evaluating and modeling methane production. Journal of
Environmental Management. 183, 551, 2016.

32. MUMME J., LINKE B., TÖLLE R. Novel upflow anaerobic solid-state (UASS) reactor. Bioresour. Technol. 101, 592, 2010.

33. CHARLES W., WALKER L., CORD-RUWISCH R. Effect of pre-aeration and inoculum on the start-up of batch thermophilic anaerobic digestion of municipal solid waste. Bioresource Technology. 100 (8), 2329, 2009.

34. LASTELLA G., TESTA C., CORNACHIA G., NOTORNICOLA M., VOLTASIO F., SHARMA V.K. Anaerobic digestion of semi-solid organic waste: biogas production and its purification. Energy Conservation and Management. 43 (1), 63, 2002.

35. FABIEN M. An introduction to anaerobic digestion of organic wastes. Final report, Remade Scotland, 2003. http:// www.remade.org.uk

36. KARAGIANNIDIS A., PERKOULIDIS G. A multi-criteria ranking of different technologies for the anaerobic digestion for energy recovery of the organic fraction of municipal solid wastes. Bioresour. Technol. 100, 2355, 2009.

37. WARD A.J., HOBBS P.J., PETER H.J., DAVID J.L. Optimisation of the anaerobic digestion of agricultural resources. Bioresource Technology. 99,7928, 2008

38. FEZZANI B., CHEIKH R.B. Two-phase anaerobic codigestion of olive mill wastes in semi-continuous digesters at mesophilic temperature. Bioresour. Technol. 101, 1628, 2010.

39. DEMIRER G.N., CHEN S. Two-phase anaerobic digestion of unscreened dairy manure. Process Biochem. 40, 3542, 2005.

40. WEILAND P. State of the art of solid-state digestionrecent developments. In: Rohstoffe, F.N. (edt), Solid-State Digestion-State of the Art and Further R\&D Requirements. Volume 24, Gulzower Fachgespräche, pp. 22- 38, 2006.

41. KARTHIKEYAN O.P., VISVANATHAN C. Bio-energy recovery from high-solid organic substrates by dry anaerobic bio-conversion process: a review; Rev Environ Sci Biotechnol. 12 (3), 257, 2013.

42. SURROOP D., MOHEE R. Comparative assessment of anaerobic digestion of municipal solid waste at mesophilic and thermophilic temperatures. Int $\mathrm{J}$ Environ Technol Manag. 14 (1/2/3/4), 238, 2011.

43. DEUBLEIN D., STEINHAUSER A. Biogas from Waste and Renewable Resources. An Introduction. Wiley-VCH Verlag GmbH \& Co. KGaA, 2008, ISBN: 9783527621705 , DOI: $10.1002 / 9783527621705$.

44. RÜCKER C., KÜMMERER K. Environmental Chemistry of Organosiloxanes. Chemical Reviews. 115 (1), 466, 2015.

45. HE P.J. Anaerobic digestion: an intriguing long history in China. Waste Management. 30 (4), 549, 2010.

46. RAJENDRAN K., ASLANZADEH S., TAHERZADEH M.J. Household Biogas Digesters. Energies. 5 (8), 2911, 2012.

47. TAMBONE F., SCAGLIA B., D'IMPORZANO G., SCHIEVANO A., ORZI V., SALATI S., ADANI F. Assessing amendment and fertilizing properties of digestates from anaerobic digestion through a comparative study with digested sludge and compost. Chemosphere. 81 (5), 577, 2010.

48. HUGH M. Agricultural Composting Basics. Organic Crops Production Program Lead/OMAFRA, 2015. http://www. omafra.gov.on.ca/english/engineer/facts/05-023.htm

49. SINGH S., NAIN L. Microorganisms in the Conversion of Agricultural Wastes to Compost. Proc Indian Natn Sci Acad. 80 (2), 473, 2014.

50. SHAMMAS N.K., WANG L.K. Aerobic Digestion. In: 
Biosolids Treatment Processes, Handbook of Environmental Engineering, 6, 177, 2007.

51. MICHALAK I., TUHY L., CHOJNACKAK. Co-composting of Algae and Effect of the Compost on Germination and Growth of Lepidium sativum. Pol. J. Environ. Stud. 25 (3), 1107, 2016.

52. ESCOBAR N., SOLARTE V. Microbial Diversity Associated with Organic Fertilizer Obtained by Composting of Agricultural Waste. International Journal of Bioscience. Biochemistry and Bioinformatics. 5 (2), 70, 2015.

53. SADIK M.W., EL SHAER H.M., YAKOT H. M. Recycling of Agriculture and Animal Farm Wastes into Compost Using Compost Activator in Saudi Arabia. J. Int. Environmental Application \& Science. 5 (3), 397, 2010.

54. ITALIAN AGENCY FOR DEVELOPMENT COOPERATION (Lebanon and Syria). Composting from A to Z, 2011. http://aicsbeirut.org/portal/en-US/ publications/14/c/composting-from-a-to-Z/374/

55. KÜLCÜ R., YALDIZ O. The composting of agricultural wastes and the new parameter for the assessment of the process. Ecological Engineering. 69, 220, 2014.

56. HESS J.B., DONALD J.O., MITCHELL C.C., GILLIAM C.H. Composting Agricultural Wastes in Alabama. Alabama Cooperative Extension System (Alabama A\&M University and Auburn University), 2011, ANR-0572.

57. ZENG A., KALTSCHMITT M. Green Electricity and biowaste via biogas to bulk-chemicals and fuels: the next move toward a sustainable bioeconmy. Eng. Life Sci. 16 (3), 211, 2016.

58. SAMBO A.S., ETONIHU A.C., MOHAMMED A.M. Biogas Production from Co-digestion of Selected Agricultural Wastes in Nigeria. International Journal of Research Granthaalayah. 3 (11), 7, 2015.

59. WEILAND P. Biogas production: current state and perspectives. Appl Microbiol Biotechnol. 85, 849, 2010.

60. MUSSOLINE W., ESPOSITO G., GIORDANO A., LENS P. The Anaerobic Digestion of Rice Straw. Critical Reviews in Environmental Science and Technology. 43, 895, 2013

61. CALLAGHAN F.J., WASE D.A.J., THAYANITY K., FORSTER C.F. Continuous co-digestion of cattle slurry with fruit and vegetable wastes and chicken manure. Biomass Bioenergy. 22, 71, 2002.

62. ESPOSITO G., FRUNZO L., LIOTTA F., PANICO A., PIROZZI F. BMP tests to measure the biogas production from the digestion and co-digestion of Complex organic substrates. Open J Environ Eng. 5, 1, 2012.

63. SØNDERGAARD M.M., FOTIDIS I.A., KOVALOVSZKI A., ANGELIDAKI I. Anaerobic Co-digestion of Agricultural Byproducts with Manure for Enhanced Biogas Production.
Energy Fuels. 29 (12), 8088, 2015.

64. PAGÉS-DÍAZ J., PEREDA-REYES I., TAHERZADEH M.J., SÁRVÁRI-HORVÁTH I., LUNDIN M. Anaerobic codigestion of solid slaughterhouse wastes with agro-residues: Synergistic and antagonistic interactions determined in batch digestion assays, Chemical Engineering Journal. 245, 89, 2014.

65. BRAUN R., WELlingeR A. Potential of Co-digestion. IEA Bioenergy, Task 37, 2001. https://www.iea-biogas.net/ files/daten-redaktion/download/publi-task37/Potential\%20 of $\% 20$ Codigestion $\% 20$ short $\% 20$ Brosch 221203 .pdf

66. BUDZIANOWSKI W. Potential innovations for production, conditioning and utilization of biogas with multiple-criteria assessment. Renewable and Sustainable Energy Reviews. 54, 1148, 2016.

67. HEO N.H., PARK S.C., KANG H. Effects of mixture ratio and hydraulic retention time on single-stage anaerobic codigestion of food waste and waste activated sludge. J Environ Sci Health A Tox Hazard Subst Environ Eng. 39 (7), 2004.

68. ZHANG R., EL-MASHAD H.M., HARTMAN K., WANG F., LIU G., CHOATE C. Characterization of food waste as feedstock for anaerobic digestion. Bioresource Technology. 98 (4), 929, 2007.

69. CHEN X., ROMANO R.T., ZHANG R. Anaerobic digestion of food wastes for biogas production. Int J Agric \& Bio Eng. 3 (4), 61, 2010.

70. ALAA EL-DIN M.N., GOMAA H.A., EL-SHIMI S.A., ALI B.E. Biogas Production from Kitchen Refuses of Army Camps of Egypt using a two Stage Biogas Digester. In: El-Halwagy M.M. (ed.), Biogas Technology, Transfer and Diffusion, Elsevier Applied Science Publishers Ltd, 589, 1986.

71. COSTA M.S.S. DE M., CARNEIRO L.J., COSTA L.A. DE M., PEREIRA D.C., LORIN H.E.F. Composting Time reduction of Agro-industrial Wastes. Journal of the Brazilian Association of Agricultural Engineering. 36 (6), 1206, 2016.

72. AL-BARAKAH F.N., RADWAN S.M.A., ABDEL-AZIZ R.A. Using Biotechnology in Recycling Agricultural Waste for Sustainable Agriculture and Environmental Protection. Int. J. Curr. Microbiol.App.Sci. 2 (12), 446, 2013.

73. SEAM (Solid Waste Management). Case study: 150 tpd compost plant, Mansoura, Egypt, 1999. http://www.eeaa. gov.eg/seam/CaseStudies/SW_Compost.PDF

74. LUSKE B. Reduced $\mathrm{GHG}^{-}$emissions due to compost production and compost use in Egypt. Report of Louis Bolk Institute, the Netherlands, 2010. http://orgprints. org/17480/4/17480.pdf 